Горбачова О. М., к.е.н., доцент Національний авіаційний університет м. Київ, Украӥна

DOI: https://doi.org/10.30525/978-9934-26-080-3-5

\title{
ПЕРЕДУМОВИ ЦИКЛІЧНОГО РОЗВИТКУ АЕРОПОРТОВИХ КОМПЛЕКСІВ ТА ФАКТОРИ, ЩО ЙОГО ВИЗНАЧАЮТЬ
}

Циклічність розвитку аеропортових комплексів $є$ тією проблемою, яка науковою літературою певним чином ігнорується, оскільки увага сучасних науковців переважно сконцентрована на вивченні циклічності розвитку комерційних організацій в контексті їхньої ринкової активності, і життєвий шлях яких можна прослідкувати у відносно короткому часовому інтервалі.

У той час як довгі життєві цикли, наприклад, життєві цикли залізничних вокзалів, які налічують сотні років, або ж 
аеропортів, які налічують десятки років та мають тенденцію до «безкінечного» життя, не приваблюють науковців, які розробляють теорію організації. Вважається, що такі організації $\epsilon$ по суті «безсмертними», відповідно, з точки зору теорії життєвих циклів, їх дослідження $є$ безперспективним.

Другим фактором, який впливає на те, що життєвий цикл аеропортів не викликає цікавості у дослідників $є$ те, що рішення відносно перспектив їх розвитку приймаються на державному рівні, відповідно ринкові умови їх функціонування стають другорядним фактором i, таким чином, аеропорти «випадають» і3 загального переліку комерційних організацій, що також не стимулює наукового пошуку.

На думку автора, такий науковий підхід не є виправданим, оскільки останні роки підтвердили, що аеропорти мають кінцевий життєвий цикл (аеропорт Ізмаїл), в той же час аеропорт в своєму розвитку може впритул наблизитися до останніх стадій життєвого циклу, відповідно наукові розробки в цьому напрямі можна вважати актуальними.

На думку автора, нині теорія життєвого циклу комплексів аеропортів в цілому являє синтез різних понять і категорій, які поєднують економічну теорію, стратегічний i антикризовий менеджмент. Як правило, використовують окремі фрагменти теорії циклів, однак загальної теоретичної концепції управління аеропортовими комплексами за стадіями життєвого циклу створити поки що не вдалося. У той же час автор переконаний, що циклічність розвитку аеропортових комплексів обумовлена факторною складовою, яка впливає на їх діяльність.

Дія першого фактору виявляється в тому, що аеропорти - це складні соціально-економічні системи, які розвиваються за загальними законами розвитку організацій з тим обмеженням, що для більшості з них не характерні останні стадії життєвого циклу, про що вже йшлося вище.

У науковій літературі під аеропортом розуміється комплекс споруд, що включають аеродром, аеровокзал, інші споруди, призначений для прийому i відправки повітряних суден, 
обслуговування повітряних перевезень i має для цих цілей необхідне обладнання, авіаційний персонал та інших працівників [1].

Як зазначають Н. Ашфорд, Х.П.М. Стентон, К.А. Мур, аеропорт - це багатофункціональне транспортне підприємство, що $є$ наземною частиною авіаційної транспортної системи, яка забезпечує зліт і посадку повітряних суден та їх наземне обслуговування, прийом і відправлення пасажирів, багажу, пошти і вантажів, а також створює необхідні умови для функціонування авіакомпаній, державних органів регулювання авіаційною, митною та іншими діяльностями, сприяє діловій активності, спрямованій на поліпшення рівня обслуговування пасажирів та інших клієнтів - споживачів авіа послуг і забезпечення економічної стабільності аеропорту [1, с. 32].

Маємо погодитися із В.В. Запорожцем та М.П. Шматко в тому, що аеропорт - це складна система, що включає підрозділи та служби, метою яких $є$ забезпечення перевезень повітряним транспортом. Так, деякі з них спрямовані на обслуговування потоку пасажирів, а інші - на обслуговування повітряних суден [2].

Безумовно, що аеропортові комплекси можна розглядати як складну соціально-економічну систему, яка складається 3 аеродромного, аеронавігаційного, перонного й аеровокзального комплексів, а також допоміжних підрозділів, забезпечуючи їх функціонування. Вважається загальноприйнятим основні напрями діяльності аеропорту поділяти на:

1. Авіаційну діяльність, тобто виробничо-господарську діяльність на території аеропорту юридичних осіб та індивідуальних підприємців із забезпечення польотів, прийому та відправки повітряних суден (ПС), обслуговування пасажирів, обробки пошти, багажу та вантажу, яка здійснюється на основі встановлених вимог щодо забезпечення безпеки польотів.

2. Неавіаційну діяльність, яка включає перелік сервісних послуг на комерційній основі для споживачів, зокрема: торгівля, 
об'єкти харчування, побутові об'єкти, паркування, обмін валют, duty free та інше [1, с. 102].

Важливо розуміти, що аеропорти як система обслуговування функціонують у сфері надання послуг і відрізняються від інших підприємств рядом аспектів, які впливають на оцінку їх діяльності. Серед них можна виділити: відмінність кінцевого продукту (кінцевий продукт - це послуга, рівень обслуговування, а не вироблений товар, що має відчутну матеріальну форму); високий організаційний і технологічний рівень і технічно складні умови; обслуговування на міжнародному рівні i в рамках політичної структури високого рівня; цілодобовий характер обслуговування; можливість виникнення аварійних ситуацій у будь-який час; обслуговування як авіаційних пасажирів, так i власників (супровідників) вантажів, що перевозяться.

До переліку послуг, які аеропорт надає авіакомпаніям, належать: зліт та посадка (включаючи користування світлосигнальним обладнанням та аеродромним диспетчерським обслуговуванням); обслуговування пасажирів; обробка вантажів; надання у користування місць стоянок та ангарів; забезпечення безпеки; наземне обслуговування повітряних суден; додаткові послуги.

Разом з наданням послуг, пов'язаних 3 авіаційною діяльністю, аеропорт забезпечує комплекс послуг, безпосередньо з нею не пов'язаних, а саме: оренда приміщень, територій, обладнання, майна; тепло- та електрозабезпечення об'єктів на території аеропорту; водопостачання об'єктів; послуги зі зберігання вантажів на складах; обробка цінних вантажів та багато інших.

Загальний стан цієї складної системи визначає і цикл, на якому в конкретний момент часу знаходиться аеропортовий комплекс.

Циклічність розвитку аеропортових комплексів $є$ їх ознакою, яка виявляється і в тому, що за багато років аеропорти пройшли відповідний шлях розвитку, розвинулися від інфраструктурних суб'єктів повітряних перевезень до центрів ділової активності, включаючи магазини аеропортів, об'єкти розваг, об'єкти торгівлі продуктами харчування і т. ін. 
У той же час в останні роки аеропорти, які не витримують конкуренції, втрачають своє значення як суб'єкт транспортної інфраструктури, зменшується їх кількість за рахунок закриття аеропортів, які не відповідають вимогам безпечності, екологічності, технологічності, не мають перспектив розвитку 3 точки зору розвитку ринку авіаційних перевезень.

Сучасні аеропорти навряд чи доцільно відносити до «безсмертних» організаційних систем, що підтверджує актуальність обраного напряму дослідження.

Циклічність розвитку аеропортових комплексів має під собою об'єктивні підстави, які також пов'язані з історичним розвитком системи авіаперевезень, а також із змінами в їх організації. Також слід наголосити і на тому, що великі аеропорти мають значні переваги в контексті циклічності розвитку, оскільки, входячи до стратегічних елементів транспортної інфраструктури, вони, як правило, в своєму розвитку не доходять до останніх етапів життєвого циклу завдяки державній підтримці (Бориспіль, Шереметьєво та ін.).

Розглядаючи циклічність розвитку аеропортових комплексів в історичній ретроспективі, слід звернути увагу на те, що перші етапи їхнього розвитку визначалися недосконалістю технічного забезпечення авіаперевезень.

Щоб впоратися 3 обслуговуванням великого числа рейсів прибуття і відправлення в години пік, служби аеропортів почали використовувати нове обладнання і методи обслуговування, що дозволило істотно скоротити терміни переміщення пасажирів, багажу та вантажів 3 одних літаків на інші, підвищити інтенсивність використання злітно-посадкових смуг і повітряного простору аеропорту.

Розвиток аеропорту після завершення його будівництва відбувається, як правило, досить повільно, зводиться до поступового збільшення пропускної здатності його злітнопосадкової смуги і аеровокзалів і закінчується 3 вичерпанням можливостей розширення та введенням в цій місцевості нового аеропорту майже через 20 років. Проте в деяких регіонах, 
наприклад, у Південно-Східній Азії, де в останні десятиліття спостерігається бурхливе економічне зростання, в 2000-х роках мало місце надзвичайно інтенсивне будівництво численних нових аеропортів.

Отже, об'єктивно існуючий циклічний процес розвитку аеропортових комплексів має вирішальний вплив на їх ділову активність і подальший розвиток, що зумовлює потребу в аналізі історичних аспектів життєвого циклу українських аеропортових комплексів.

\section{Лiтература:}

1. Ашфорд Н., Стентон Х.П.М., Мур К.А. Функционирование аэропорта / пер. с англ. В.И. Ноздрина. Москва : Транспорт, 1991. 372 с.

2. Запорожець В.В., Шматко М.П. Аеропорт: організація, технологія, безпека. Київ : Дніпро, 2002. 168 с. 